\title{
California looks to science partnerships ...
}

Sacramento, California. A formidably powerful science and technology base is helping to lift California out of its longest recession since World War Two. But new types of partnerships between science, industry and local government are needed to sustain the state's recovery, according to participants attending the California Coalition for Science and Technology Summit, held in Sacramento last week.

The meeting, which was organized by the University of California at Davis and sponsored by Californian corporations and local and federal agencies, failed to reach a clear consensus on what California should do to reinforce its science and technology base. But it did agree that various parts of the state needed to work harder to emulate the world-beating performance of its strongest regions - Silicon Valley and San Diego.

The meeting's recommendations were:

- Less resistance from universities to direct contact between faculty and industry. "The universities have not done a very good job" in technology transfer, admits Richard Atkinson, president of the University of California (UC) system. State laws inhibiting the commercial activities of UC faculty are among the most restrictive in the United States, other participants said.

- Better technical education in high schools. Delegates raised this issue more often than any other - but when Dan Goldin the administrator of NASA, asked how many people in the hall spent time helping schools, scarcely a hand went up.

- Stronger regional, non-profit groups to foster ties between universities, government laboratories, industry, local government and venture capitalists.
- Cheaper means of accessing science inside government research laboratories. The giant Lawrence Livermore National Laboratory (LLNL) near Oakland was praised for its expertise, but criticized as "bureaucratic" and expensive to work with.

- Network, network and network AnnaLee Saxenian, an economist at the University of California at Berkeley, pointed out that an open and informal networking system is the basis of "Silicon Valley's unique dynamism". Traditional science-industry links, such as those between the California Institute of Technology and the aerospace and electronics industries in the Los Angeles area, were less suited to the needs of today's economy, she said.

Environmental technologies - which only two years ago were being touted as a saviour for Lawrence Livermore - were scarcely mentioned at the meeting. The impact of the loss of defence-related jobs, which dominated California's economy for fifty years, seems to have been overcome as the state races into a boom based around silicon, biotechnology and the film industry.

"A very, very dramatic recovery" delivered a net gain of 300,000 jobs to California last year, says Tapan Munroe, chief economist at Pacific Gas and Electric. "The renaissance of California is being driven by science,"was the economist's bullish verdict.

Although the state houses only 12 per cent of the US population, it attracts onequarter of federal research and development spending (see figure). It also hosts the world's three largest biotechnology companies - Chiron, Amgen, and Genentech -

\section{and supports medical research}

Sacramento. Californians overwhelmingly approve of federal support for biomedical research, and many would even pay higher taxes to fund more of it, according to a public opinion poll. But only one in twenty-five of those interviewed identified correctly the National Institutes of Health (NIH) - which has an annual budget of $\$ 12$ billion - as the government organization that pays for the research.

The obscurity of NIH contrasts sharply with the celebrity of NASA, which 53 per cent of those polled identified as the space agency, and the Food and Drug Administration (FDA), which 67 per cent identified as the body approving drugs and medical devices.

"Historically, NIH has been comfortable with its role in the background," explains Ed Penhoet, president of Chiron, the biotechnology company.
Asked if they approved of federal funding for medical research in universities, 86 per cent of those polled said yes, and 51 per cent thought it should be increased. Seventy per cent considered the federal dollars already spent good value, a slightly higher proportion than those who felt the same about spending on defence (64 per cent), social security (62 per cent) and public education ( 55 per cent).

Over half said that in principle they would even be willing to pay an extra dollar a week in taxes to support medical research. Three quarters of those questioned supported the use of animals for medical research, while one-fifth opposed it. The poll was commissioned by Research!California, a branch of Research!America, a group which aims to foster public support for science.

C. $M$.

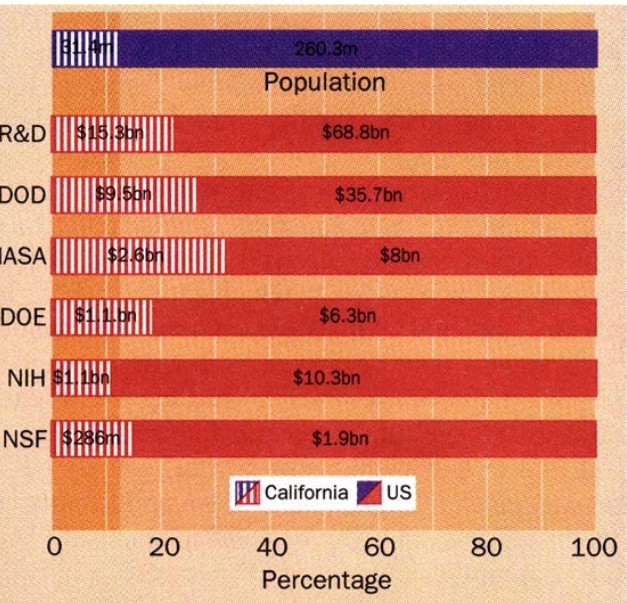

How California fares in federal research funds.

and biotechnology provides 165,000 jobs, at an average annual wage of $\$ 50,000$.

In the new multimedia industry, California has more young firms than the rest of the United States combined. As an omen for the future, it is studded with "little giants" such as Netscape, the Internet services company, which already has a stock market value of $\$ 4$ billion.

Against this optimistic backdrop, Ernie Moniz, associate director for basic science at the White House's Office of Science and Technology Policy (OSTP), warned that California could be hard hit by cuts in the research activities of the federal government. Congress's plans for this year could cut $\$ 100$ million in California alone, he said.

And some support was voiced for a mechanism to prioritize science and technology spending in the state. Dan Thompson, of the manufacturing technology programme at LLNL, points out that California has "no broadly based structure to make resource decisions" for research and development. "There are even some who say it doesn't need it," he says.

One supporter of this point of view is Charlene Simmons, who works for the research service of the state government in Sacramento. "Maybe we're better off without a state science and technology programme," says Simmons, adding that the state civil service is "too slow" to administer such a programme efficiently.

But informal coordination, probably orchestrated through local groups, will definitely increase as people learn from the trauma of the recent slump. "The stress has opened people's eyes to what has to be done if they're not going to be stressed again," says M. R. C. Greenwood, chancellor-elect of the University of California at Santa Cruz, who came up with the idea of the summit during her period at the OSTP. "This felt like the right meeting," she says. "Its success will encourage more participation in partnerships".

Colin Macilwain 